Research Article

\title{
Academic Performances and Associated Factors Amongst School Adolescents: A Cross Sectional Study
}

\author{
Jugal Kishore, Heena $^{2}$, Tanu Anand ${ }^{3}$, Tamanna Nazli ${ }^{4}$, Ranjit Kumar Mandal ${ }^{5}$ \\ ${ }^{1}$ Director Professor \& Head Community Medicine, VMMC \& SJH New Delhi. \\ ${ }^{2}$ Research Scholar, ICMR Project Community Medicine, VMMC \& SJH New Delhi. \\ ${ }^{3}$ Scientist D, DHR, ICMR, New Delhi. \\ ${ }^{4}$ Research Officer, Central Council for Research in Unani Medicine, MoAYUSH, Govt. of India. \\ ${ }^{5}$ Principal, BGS World School, Chikballapur, Karnataka. \\ DOI: https://doi.org/10.24321/2455.9199.201907
}

\section{I $\quad \mathbf{N} \quad \mathbf{F} \quad \mathbf{O}$}

\section{Corresponding Author:}

Heena, ICMR Project Community Medicine, VMMC \& SJH New Delhi.

E-mail Id:

heena.parveen.stats@gmail.com

Orcid Id:

https://orcid.org/0000-0003-4466-7475

How to cite this article:

Kishore J, Heena, Anand T, Nazli T, Mandal RK. Academic Performances and Associated Factors Amongst School Adolescents: A Cross Sectional Study. Int J HealthCare Edu \& Med Inform 2019; 6(2): 10-17.

Date of Submission: 2019-11-26

Date of Acceptance: 2019-12-18

\section{$\begin{array}{llllllll}\mathbf{A} & \mathbf{B} & \mathbf{S} & \mathbf{T} & \mathbf{R} & \mathbf{A} & \mathbf{C} & \mathbf{T}\end{array}$}

Background: Students' academic achievement and learning outcome is influenced by various factors including age, gender, religion, preferences for the future career and family background.

Objectives: 1) To study the effect of various factor on academic performances of school adolescents and 2) to find out the association with Socio-Demographic Characteristics among these students.

Methods: It was a school based cross sectional study conducted in one of the private schools in Chikballapur, Karnataka. Data from 591 adolescents of classes 6 th-10th was collected by a questionnaire. The questionnaire contained 4 factors with 76 questions, each relating to different aspects of a child or adolescent's life and how they felt about those. Data was presented as frequency tables and significant association was established by one-way ANOVA, t-test and multiple linear regression.

Result: As age advanced favorable educational factors, mental/emotional factors and social factors decreased significantly but had no effect on health factors. No significant association existed between religion and various domains of health and wellbeing $(p>0.05)$ of the students. Except the educational factors which was higher in females, no other factors were significantly associated with gender. As aggregate percentage in previous examinations increased, the favorable educational factors, health factors and mental/ emotional factors increased significantly but had no effect on social factors.

Conclusions: Scores of health and wellbeing of the student were significantly associated with age, gender and preferences for the future subject and academic performances. Knowing these factors may help to undertake corrective measures that improve the academic achievement of school adolescents.

Keywords: Adolescent, School, Education, Mental, Social, Health, Development, Academic Performances 


\section{Introduction}

Adolescence is a pivotal period in person's life as it bridges the gap between childhood and adulthood. It is the period of fast and vast development in all fields - educational, health, mental/emotional and social factors.

Education is a single and vital way to the success as well as the personal growth. It develops personality of people, provides physical and mental standard and transforms people's living status. As Nelson Mandela said, "Education is the most powerful weapon which you can use to change the world."

Mental health during adolescence is of utmost importance for overall wellbeing and development in adulthood. Mental disorders are experienced by $10-20 \%$ of children and adolescents worldwide. Most of the illnesses emerge at the age of 14 and three-quarters by mid-20s. If left neglected, these conditions severely effect children's development, educational achievement and potential to live productive lives. ${ }^{1}$

It is the age when one may even attempt to commit suicide. Adolescents, generally, happen to be very ambitious too they dream of becoming great (by often emulating their models); and when hurdles, one after the other, break their dreams, they get frustrated. The academic pressure is also one of the major causes for the stress. ${ }^{2}$ Interpersonal violence was found to be significantly more in males than females. ${ }^{3}$ Anand et al, highlights that type of school, gender and attitude of the student influence adolescents' behavior towards aggression. ${ }^{4}$

This phase of adolescence is the building block of wholesome adulthood and old. Adolescence is the period when one moves into a continuously widening circle of companions. Students come in contact with one another while indulging in curricular and co-curricular activities such as games, sports, scouting, outing, excursions or tours or picnic and so on. An adolescent becomes keenly interested in moving with his companions. All this makes the adolescent very much social; and, the environments provided by these different social circles help in his multi-faceted development. ${ }^{5}$ Students can do better in every sphere of life if they are correctly guided by the teacher and parents. ${ }^{6}$

The present study aims at studying the effect of various factors on academic performances of school adolescents and to find out its association with socio-demographic characteristics among these students.

\section{Methods}

\section{Study Design}

It was a school based cross-sectional study.

\section{Study Area and Study Population}

The study was conducted in the semi-urban area of
Chikballapur district in Karnataka. It is a private school having classes from 1st to 10th standard. Students from rural as well as urban areas are coming to attend the school. Study population comprised of students studying in classes 6 th to 10 th standards.

\section{Study Sample and Duration}

The data collection of the study was done in the month of August-September 2017. A total of 591 students participated in the study. To recruit the students, permission was sought from the principal of the school. After obtaining the written consent form the principal, questionnaires were distributed to the students in their classrooms during a pre-fixed time. Efforts were made to ensure that the students had privacy while completing the questionnaire.

\section{Study Tool}

A pre-designed, pre-tested, semi-structured, selfadministered questionnaire was used for data collection. Data was collected regarding the socio-demographic variables like age, gender, religion, aggregate percentage of marks in previous year's annual examination and three subjects that students liked the most. For internal consistency Cronbach's alpha was used.

Table I.Results of internal consistency analysis of the school adolescent health scale

\begin{tabular}{|c|c|c|}
\hline Factors & $\begin{array}{c}\text { Cronbach's } \\
\text { Alpha }\end{array}$ & $\begin{array}{c}\text { No. of questions } \\
\text { clubbed in a } \\
\text { factor }\end{array}$ \\
\hline Educational factor & 0.58 & 15 \\
\hline Health factor & 0.42 & 15 \\
\hline $\begin{array}{c}\text { Mental/ Emotional } \\
\text { factor }\end{array}$ & 0.68 & 30 \\
\hline Social factor & 0.43 & 16 \\
\hline Total health score & 0.78 & 76 \\
\hline
\end{tabular}

For internal consistency, Cronbach's alpha was used. Cronbach's alpha is acceptable when it is $>=0.7$. The questionnaire had sufficient reliability, with a Cronbach's alpha of 0.78 for the health score and 0.68 for Mental/ Emotional factor.

\section{Statistical Analysis}

After collection of data it was double entered in Microsoft Excel Sheet and validated. A clean database was generated and analysed in SPSS (version 16.0). Data were presented by using frequency tables. Distribution of study population according to age, gender, religion, aggregate percentage of marks in previous year's annual examination and three subjects that students liked the most were analysed. Association of total health scores with different sociodemographic parameters were also analysed. One-way 
ANOVA, t- test and multiple linear regression of significance was performed to find out the association. P-value $<0.05$ was considered as significant.

Ethical Issues: Permission was obtained from the principal of the concerned school and assent was taken from the participants. Participants were assured of the confidentiality and were free to decline from participation in the study at any point of time.

\section{Result}

\section{The Socio-demographic Characteristics of the Sample}

According to Table 2, out of 591 students, 131 (22.2\%) of the students belonged to age distribution of 9-12 years and $17-20$ years each and $329(55.7 \%)$ of the students belonged to age distribution of 13-16 years. While the majority 554 (93.7\%) of the students were found to be Hindus, 31 (5.3\%) of the students were Muslim and only few $6(1.02 \%)$ of the students were Christians. As to the gender, 309 (52.3\%) of the students were male and $282(47.7 \%)$ of the students were female.

Significant association exists between age and educational factor. Mean value of educational factor was significantly higher in students aged 9-12 years and mean value was significantly lower in the students aged $17-20$ years. No significant association exists between age and health value $(p=0.960)$ which is almost uniform over the age. Significant association exists between age and mental factor. $(P<0.05)$ mean value of mental factor was significantly higher in the students aged 9-12 years and significantly lower in the age group 17-20 years. Significant association exists between age and social factor $(P<0.05)$. Mean value of social factor was significantly higher in the students in the age group 9-12 years and significantly lower in age group $17-20$ years.

No significant association exists between religion and health scores ( $p>0.05$ ). Mean value of educational factor in Hindus was 11.16 \pm 2.44 , for Christians was $10.83 \pm 2.14$ and for Muslims was 11.03 \pm 1.74 . Mean value was higher in Hindu and lower in Christians. In health factor, mean value of Hindu was $9.20 \pm 2.18$, for Christians was $8.83 \pm 1.60$ and for Muslims was $9.39 \pm 2.85$. In mental factor, mean value of Hindu was $19.29 \pm 4.10$, for Christians was $21.33 \pm 3.78$ and for Muslims was 20.03 \pm 3.79 . In social factor, mean value of Hindu was $11.03 \pm 2.28$, for Christians was $10.67 \pm 1.63$ and for Muslims was $11.77 \pm 1.86$. Except the educational factors, mean value $11.55 \pm 2.33$ was higher in females and no other factors were significantly associated with gender.

According to Table 3, aggregate percentage of majority 272 (50.60\%) of the students belonged to $61-80,191$ (35.50\%) of the students belonged to $81-100$ and $75(13.90 \%)$ of the students belonged to the interval 41-60.

Significant association exists between aggregate percentage in last examination and educational factors, health factors and mental/ emotional factors $(P<0.05)$. As aggregate percentage in previous examination increases favorable educational factors, health factors and mental/emotional factors increase significantly but has no effect on social factors.

Table 2.Association of Total Health Scores According to Different Socio-demographic Parameters

\begin{tabular}{|c|c|c|c|c|c|}
\hline \multirow[t]{2}{*}{ Variables } & \multirow{2}{*}{$n_{i}(\%)$} & $\begin{array}{c}\text { Educational factors } \\
\text { (items=15) }\end{array}$ & $\begin{array}{l}\text { Health factors } \\
\text { (items=15) }\end{array}$ & $\begin{array}{l}\text { Mental/ Emotional } \\
\text { factors (items=30) }\end{array}$ & $\begin{array}{c}\text { Social factors } \\
\text { (items=16) }\end{array}$ \\
\hline & & Mean $\pm S D$ & Mean $\pm S D$ & Mean $\pm S D$ & Mean $\pm S D$ \\
\hline \multicolumn{6}{|c|}{ Age (in years) } \\
\hline $9-12$ & $131(22.20 \%)$ & $12.16 \pm 2.35$ & $9.24 \pm 2.26$ & $20.39 \pm 4.19$ & $11.24 \pm 2.41$ \\
\hline $13-16$ & $329(55.70 \%)$ & $11.13 \pm 2.27$ & $9.18 \pm 2.19$ & $19.35 \pm 3.97$ & $11.19 \pm 2.22$ \\
\hline $17-20$ & $131(22.20 \%)$ & $10.17 \pm 2.38$ & $9.22 \pm 2.24$ & $18.32 \pm 4.05$ & $10.56 \pm 2.15$ \\
\hline \multicolumn{2}{|c|}{ P-value } & 0.001 & 0.96 & $0.001^{*}$ & $0.01 *$ \\
\hline \multicolumn{6}{|c|}{ Religion } \\
\hline Hindu & 554 (93.70\%) & $11.16 \pm 2.44$ & $9.20 \pm 2.18$ & $19.29 \pm 4.10$ & $11.03 \pm 2.28$ \\
\hline Christian & $6(1.00 \%)$ & $10.83 \pm 2.14$ & $8.83 \pm 1.60$ & $21.33 \pm 3.78$ & $10.67 \pm 1.63$ \\
\hline Muslim & 31 (5.30\%) & $11.03 \pm 1.74$ & $9.39 \pm 2.85$ & $20.03 \pm 3.79$ & $11.77 \pm 1.86$ \\
\hline \multicolumn{2}{|c|}{ P-value } & 0.915 & 0.826 & 0.303 & 0.181 \\
\hline \multicolumn{6}{|c|}{ Gender } \\
\hline Male & 309 (52.30\%) & $10.77 \pm 2.41$ & $9.33 \pm 2.22$ & $19.37 \pm 4.21$ & $11.09 \pm 2.18$ \\
\hline Female & $282(47.70 \%)$ & $11.55 \pm 2.33$ & $9.07 \pm 2.20$ & $19.33 \pm 3.96$ & $11.03 \pm 2.35$ \\
\hline \multicolumn{2}{|c|}{ P-value } & $0.001^{*}$ & 0.15 & 0.923 & 0.738 \\
\hline
\end{tabular}

${ }^{*}$ p-value $<0.05$ 
Table 3.Distribution of various Health Scores according to percentage in last examination

\begin{tabular}{|c|c|c|c|c|c|}
\hline $\begin{array}{c}\text { Aggregate } \\
\text { percentage } \\
(\mathbf{N}=5 \mathbf{5 3})\end{array}$ & \multirow{2}{*}{$\mathbf{n}_{\mathbf{i}}(\mathbf{\%})$} & $\begin{array}{c}\text { Educational } \\
\text { factor (items=15) }\end{array}$ & $\begin{array}{c}\text { Health factor } \\
\text { (items=15) }\end{array}$ & $\begin{array}{c}\text { Mental/Emotional } \\
\text { (items=30) }\end{array}$ & $\begin{array}{c}\text { Social factor } \\
\text { (items=16) }\end{array}$ \\
\cline { 3 - 6 } & & Mean \pm SD & Mean \pm SD & Mean \pm SD & Mean $\pm S D$ \\
\hline $41-60$ & $75(13.90 \%)$ & $10.65 \pm 2.55$ & $8.51 \pm 2.13$ & $18.31 \pm 3.59$ & $11.01 \pm 2.13$ \\
\hline $61-80$ & $272(50.60 \%)$ & $11.05 \pm 2.27$ & $9.17 \pm 2.16$ & $19.31 \pm 3.87$ & $11.06 \pm 2.29$ \\
\hline $81-100$ & $191(35.50 \%)$ & $11.62 \pm 2.42$ & $9.50 \pm 2.31$ & $19.91 \pm 4.58$ & $11.13 \pm 2.34$ \\
\hline \multicolumn{2}{|c|}{ P-value } & 0.004 & 0.004 & 0.015 & 0.916 \\
\hline
\end{tabular}

Table 4.Association of Total Health Scores according to Different Socio-demographic Parameters

\begin{tabular}{|c|c|c|c|c|c|}
\hline \multirow{2}{*}{$\begin{array}{c}\text { Subject } \\
\text { preference }\end{array}$} & \multirow{2}{*}{$n_{i}(\%)$} & \begin{tabular}{|c|}
$\begin{array}{c}\text { Educational } \\
\text { factor (items }=15)\end{array}$ \\
\end{tabular} & $\begin{array}{l}\text { Health factor } \\
\text { (items=15) }\end{array}$ & $\begin{array}{c}\text { Mental/Emotional } \\
\text { (items }=30 \text { ) }\end{array}$ & $\begin{array}{c}\begin{array}{c}\text { Social factor } \\
\text { (items=16) }\end{array} \\
\end{array}$ \\
\hline & & Mean \pm SD & Mean \pm SD & Mean \pm SD & Mean \pm SD \\
\hline \multicolumn{6}{|c|}{ First preference $(\mathrm{N}=571)$} \\
\hline Arts & $211(37 \%)$ & $10.95 \pm 2.36$ & $9.01 \pm 2.20$ & $18.85 \pm 4.13$ & $11.00 \pm 2.28$ \\
\hline Commerce & $230(40.20 \%)$ & $11.12 \pm 2.35$ & $9.36 \pm 2.24$ & $19.41 \pm 4.09$ & $10.96 \pm 2.27$ \\
\hline Science & $130(22.80 \%)$ & $11.68 \pm 2.38$ & $9.31 \pm 2.18$ & $20.25 \pm 3.96$ & $11.45 \pm 2.14$ \\
\hline \multicolumn{2}{|c|}{ P-value } & 0.018 & 0.226 & 0.009 & 0.108 \\
\hline \multicolumn{6}{|c|}{ Second preference $(\mathrm{N}=569)$} \\
\hline Arts & $223(39.20 \%)$ & $11.30 \pm 2.31$ & $9.11 \pm 2.14$ & $19.58 \pm 3.79$ & $11.38 \pm 2.04$ \\
\hline Commerce & $162(28.50 \%)$ & $10.91 \pm 2.40$ & $9.23 \pm 2.32$ & $18.78 \pm 4.32$ & $10.72 \pm 2.34$ \\
\hline Science & $184(32.30 \%)$ & $11.29 \pm 2.42$ & $9.33 \pm 2.21$ & $19.67 \pm 4.22$ & $11.05 \pm 2.38$ \\
\hline \multicolumn{2}{|c|}{ P-value } & 0.209 & 0.622 & 0.088 & 0.016 \\
\hline \multicolumn{6}{|c|}{ Third preference $(\mathrm{N}=567)$} \\
\hline Arts & 226 (39.80\%) & $11.14 \pm 2.42$ & $9.07 \pm 2.24$ & $19.80 \pm 4.15$ & $11.30 \pm 2.33$ \\
\hline Commerce & 145 (25.60\%) & $10.95 \pm 2.34$ & $9.21 \pm 2.19$ & $18.70 \pm 4.07$ & $10.70 \pm 2.12$ \\
\hline Science & 196 (34.60\%) & $11.43 \pm 2.34$ & $9.39 \pm 2.21$ & $19.42 \pm 4.02$ & $11.14 \pm 2.24$ \\
\hline \multicolumn{2}{|c|}{ P-value } & 0.163 & 0.33 & 0.043 & 0.044 \\
\hline
\end{tabular}

When asked about their first preference of subject which they like most, 571 students responded to this question. Out of which 230 (40.2\%) students had commerce, 211 $(37 \%)$ students had arts and $130(22.8 \%)$ students had science as their first preference. As a second preference of subject 569 students responded and out of which, 223 (39.2\%) students had arts, 184 (32.3\%) students had science and $162(28.5 \%)$ students had commerce stream as their second preference. As a third preference of subject, 567 students responded and 226 (39.8\%) students had stated arts, 196 (34.6\%) students had stated science and 145 $(25.6 \%)$ students had stated commerce stream as their third preference (Table 4). There is a significant association between first preference and educational factor $(P=0.018)$. Mean values were higher in science and lower in arts stream. No significant association exists between first preference and health factor $(P>0.05)$. However, mean value was almost uniform in commerce and science stream and lower in arts stream. Significant association exist between first preference and mean values of mental factor $(P=0.009)$. No significant association exist between first preference and mean values of social factor $(P=0.108)$ whereas mean value was higher in students whose first preference is science and art but lower in commerce stream.

No significant association exists between second preference and educational factor, health factors and mental factors. However, significant association exist between second preference and social factor $(P<0.05)$. Mean value was higher in arts and science but lower in commerce.

No significant association exists between third preference and educational factor and health factor. Significant association exist between third preference and mental factor $(\mathrm{P}<0.05)$ where mean value was lower in commerce and higher in arts. Significant association exist between third preference and social factor $(P<0.05)$ where mean value was higher in arts and lower in commerce. 
Table 5.Univariate analysis factors affecting academic performance of school adolescents

\begin{tabular}{|c|c|c|c|c|c|}
\hline \multirow{2}{*}{ Model } & \multicolumn{2}{|c|}{ Unstandardized Coefficients } & \multirow{2}{*}{$\begin{array}{c}\text { Standardized Coefficients } \\
\text { Beta }\end{array}$} & \multirow{2}{*}{$\mathbf{t}$} & \multirow{2}{*}{ Sig. } \\
\hline & B & Std. Error & & & \\
\hline (Constant) & 77.906 & 3.703 & & 21.038 & -.001 \\
\hline Age & -.184 & .257 & -.031 & -.715 & .475 \\
\hline (Constant) & 69.988 & 1.688 & & 41.454 & .001 \\
\hline Gender & 3.577 & 1.080 & .143 & 3.313 & .001 \\
\hline (Constant) & 76.658 & 1.422 & & 53.909 & .001 \\
\hline Religion & -1.223 & 1.173 & -.045 & -1.043 & .298 \\
\hline (Constant) & 73.570 & .994 & & 74.049 & .001 \\
\hline First preference & .166 & .080 & .090 & 2.065 & .039 \\
\hline (Constant) & 73.629 & 1.007 & & 73.131 & .001 \\
\hline Second preference & .151 & .077 & .085 & 1.957 & .051 \\
\hline (Constant) & 74.441 & 1.034 & & 71.964 & .001 \\
\hline Third preference & .074 & .077 & .042 & .963 & .336 \\
\hline (Constant) & 66.198 & 2.591 & & 25.546 & .001 \\
\hline Educational factors & .810 & .226 & .155 & 3.586 & .001 \\
\hline (Constant) & 66.476 & 2.291 & & 29.020 & .001 \\
\hline Health factor & .957 & .242 & .170 & 3.957 & .001 \\
\hline (Constant) & 66.222 & 2.589 & & 25.579 & .001 \\
\hline Mental/ Emotional factors & .468 & .131 & .154 & 3.580 & .001 \\
\hline (Constant) & 73.454 & 2.714 & & 27.061 & .001 \\
\hline Social factor & .165 & .240 & .030 & .690 & .491 \\
\hline
\end{tabular}

Table 6.Multivariate analysis factors affecting academic performance of school adolescents

\begin{tabular}{|c|c|c|c|c|c|}
\hline \multirow{2}{*}{ Model } & \multicolumn{2}{|c|}{ Unstandardized Coefficients } & Standardized Coefficients & \multirow{2}{*}{ t } & Big. \\
\cline { 2 - 5 } & B & Std. Error & & 13.612 & .001 \\
\hline (Constant) & 50.866 & 3.737 & & 3.007 & 0.003 \\
\hline Gender & 3.222 & 1.072 & 0.129 & 1.831 & 0.068 \\
\hline First preference & 0.158 & 0.086 & 0.085 & 1.595 & 0.111 \\
\hline Second preference & 0.132 & 0.083 & 0.075 & 1.755 & 0.08 \\
\hline Educational factors & 0.458 & 0.261 & 0.087 & 2.759 & 0.006 \\
\hline Health factor & 0.713 & 0.259 & 0.127 & 1.614 & 0.107 \\
\hline Mental/ Emotional factors & 0.25 & 0.155 & 0.082 & & \\
\hline
\end{tabular}

Relationship between the predictor variables and performance of the students is given in table 5 . In our stepwise multiple linear regression analysis, we find a significant intercept and significant regressor variable, which we can interpret as: for every 1-unit increase in predictor variable there is change in dependent variable. In case of gender it is increasing 3.577 times in performance of students, for first preference it is increasing 0.166 times in performance of students, for educational factors it is increasing 0.810 times in performance of students, for health factor it is increasing .957 times in performances of students, and for mental/ emotional factors it is increasing 0.468 times in performances of students.

If we put all significant variables in univariate analysis into the multiple linear regression, we find that only gender and health factors are significant predictors $(p<0.05)$. Preference of subject and educational and mental health factors were not found significant to affect performance of students. 


\section{Discussion}

Education is supposed to be an enlightening process which magnifies our wisdom and knowledge. It is important for all, any factor that significantly promotes academic achievement is important because they are the future of the nation and forming a major demographic and economic force. ${ }^{7}$

In our study, as aggregate percentage in previous examination was found among those students who have significantly more favorable health factors which supports the results that those students whose health is worse had lower educational attainment than those whose health is better. $^{8}$

It is generally assumed that the students who performed better in the initial classes of their studies also performed better in future academic years at school level but in our study, inverse proportionality was seen, as age advances favorable educational factors decreases significantly or students who performed well in initial classes not performed better in future academic years. Many studies conclude that statistically the performance of student does not vary with gender either they are male or female but our findings here were contradictory the educational factors which was higher in females were significantly associated with gender. ${ }^{9}$ The study of Nisha Arora et al, observed that on average, girls achieve higher grade than boys. ${ }^{10,11}$

Saraswati Shashidhar et al. (2009) observed that social factors were increased in low achievers. ${ }^{12}$ In our study as aggregate percentage in previous examination increases, has no effect on social factors.

Religiously involved students work harder in school than non-religious students. Popular opinion holds that the more educated people are, the less religious they are but in our study no factor was significantly associated with religion. ${ }^{13}$

Durden and Ellis quoted Staffolani and Bratti, (2002) observed that higher previous performances, better the student's academic performance in future endeavors in contrast to study conducted by Reddy and Talcott in year 2006 disagree with these assumptions that future academic gains are resolute by preceding performance. In their research on the relationship between previous academic performance and subsequent achievement at university level, they found that students learning or studying at graduate level and the score secured did not predict any academic achievement at university level..$^{14,15}$

But in our study, student's educational, mental/emotional and social outcomes decreasing significantly as age increases. The score secured didn't predict any academic achievements and also the first preference of subjects was science and mean value was significantly higher in educational factors and mental/ emotional factors. As the significant two tailed value ( $p$-value) was greater than 0.05 , so we do not reject the null hypothesis and conclude that statistically, except for educational factor the performance of student do not vary with gender either they are male or female.

Many studies have been conducted in the area of student's achievement and these studies analyse the number of factors that influence the academic performance of the student. Their finding identifies students' effort, selfmotivation of students, age of student, learning preferences of students as important factors that have effect on student's academic performance in different setting. The significance of these studies lies in the need to undertake corrective measures that improve the academic achievement of school adolescents.

\section{Limitations of the Study}

It has limitation in the form of survey design, even though the researchers were trained for data collection, investigators did not have any control on the quality of the data collections and also one of the limitations of this study was missing data.

\section{Conclusion}

Health and wellbeing of the students are significantly associated with age, gender and preferences for the subject and academic performances. Therefore, intervention should be made to focus specifically on these variables, however, further studies are required to established the effect of these interventions on academic outcomes.

\section{Conflict of Interest: None}

\section{References}

1. WHO - Maternal, newborn, child and adolescent health Available from: https://www.who.int/maternal_child_ adolescent/topics/adolescence/mental_health/en/

2. Watode B K, Kishore J, Kohli C. Prevalence of Stress among School Adolescents in Delhi. Ind J Youth Adol Health 2015; 2(4): 4-9. Available from: https:// medical.adrpublications.in/index.php/IndianJYouthandAdolescentHealth/article/view/453/427 [Google Scholar].

3. Sharma R, Grover VL, Chaturvedi S. Risk behaviors related to Inter-personal violence among school and college going adolescents in south Delhi. Indian J Community Med 2008; 33(2): 85-88. Available from: http://www.ijcm.org.in/article.asp?issn=0970-0218;ye ar=2008; volume=33;issue=2; ;page $=85$;epage $=88$; aula st=Sharma [PubMed/ Google Scholar].

4. Anand T, Kishore J, Grover S, Bhave S, Yadav S. Beliefs Supporting Violence, Attitudes and Aggressive Behavior Among School Adolescents in Rural Delhi. Community 
Ment Health J 2019; 55(4): 693-701. Available from: http://springer.iq-technikum.de/article/10.1007/ s10597-018-0315-z [PubMed/ Google Scholar].

5. Top 7 Factors Affecting Period of Adolescence | Child Development. Available from: http://www. psychologydiscussion.net/child-development/top7-factors-affecting-period-of-adolescence-childdevelopment/1107.

6. Singh SP, Malik S, Singh P. Research Paper Factors Affecting Academic Performance of Students. Indian J Res Paripex 2016; 5(4): 176-178. Available from: https://www.worldwidejournals.com/paripex/article/ factors-affecting-academic-performance-of-students/ NDg1NA==/?is=1 [Google Scholar].

7. Unicef. The State of the World's Children 2011. New York: Unicef 2011. Available from: https://www.unicef. org/sowc2011/.

8. Dobewall $\mathrm{H}$, Lindfors $\mathrm{P}$, Karvonen $\mathrm{S}$, Koivusilta $\mathrm{L}$, Vainikainen M P, Hotulainen $\mathrm{R}$ et al. Health and educational aspirations in adolescence: a longitudinal study in Finland. BMC public health 2019; 19(1): 1447. Available from: https://bmcpublichealth. biomedcentral.com/articles/10.1186/s12889-0197824-8 [PubMed/ Google Scholar].

9. Ali S, Haider Z, Munir F Khan H, Ahmed A. Factors Contributing to the Students' Academic Performance: A Case Study of Islamia University Sub-Campus. Amer J Edu Res 2013; 1(8): 283-289. Available from: http:// www.sciepub.com/EDUCATION/abstract/597 [Google Scholar].

10. Arora N, Singh N. Factors Affecting the Academic Performance of College Students. i-manager's J Edu Technol 2017;14(1):47-53. Available from: https://www. imanagerpublications.com/article/13586/ [https://doi. org/10.26634/jet.14.1.13586/ Google Scholar].

11. Girls Make Higher Grades than Boys in All School Subjects, Analysis Finds. Available from: https://www. apa.org/news/press/releases/2014/04/girls-grades.

12. Shashidhar S, Rao C, Hegde R. Factors affecting scholastic performances of adolescents. Ind J Pediatrics 2009; 76(5): 495-499. Available from: https://link. springer.com/article/10.1007/s12098-009-0091-4 [PubMed/ Google Scholar].

13. Effects of Religious Practice on Education. Available from: http://marripedia.org/effects_of_religious_ practice_on_education.

14. Bratti M, Staffolani, S. 2002, 'Student Time Allocation and Educational Production Functions', University of Ancona Department of Economics Working Paper No. 170. Available from: http://www.sciepub.com/ reference/15655.

15. Reddy P and Talcott J. 2006, Predicting university success in psychology: Are subject-specific skills important?
Retrieved on July 4, 2008. Available from: http://www. aston.ac.uk/downloads/ihs/peelea/huw2006p.pdf. 